Inteligensi : Jurnal Ilmu Pendidikan Vol. 4, No.1, 2021. Hal 9-18

Tersedia online di https://jurnal.unitri.ac.id/index.php/inteligensi

ISSN 2656-601X (online)

ISSN 2656-8675 (cetak)

\title{
KEPERCAYAAN CALON GURU SEBAGAI FAKTOR KEBERHASILAN PEMBELAJARAN BERPUSAT PADA SISWA
}

\author{
${ }^{1}$ Anis Samrotul Lathifah*, ${ }^{2}$ Yuswa Istikomayanti, ${ }^{3}$ Zuni Mitasari \\ Program Studi Pendidikan Biologi, Universitas Tribhuwana Tunggadewi \\ E-mail: as.lathifah01@gmail.com*
}

\begin{abstract}
This study aims to describe teacher beliefs and see the perspective of prospective teachers in implementing microteaching practices through Lesson Study activities, especially implementing student-centered learning. This survey research involved 33 students in the fourth and third years as research subject. Data collection on the self-confidence of prospective teachers through filling out questionnaires and the results of observations made in the Basic Teaching Skills class and Field Work Practice Activities. Qualitative analysis methods and quantitative data grouping are used to determine the response of pre-service teachers in self-confidence in implementing student-centered learning. The result is that the self-confidence of prospective teachers is still at level 2 (instructive) to level 4 (responsive) both in the aspect of confidence in the student-centered learning process and the aspect of trust in building knowledge by students. The highest level of self-confidence of prospective teachers, at 5 level (reformation) has not been achieved. Through an analysis of prospective teachers' self-confidence in these aspects, it can be used as a benchmark whether the learning process is student-centered or still teacher-centered.
\end{abstract}

Keywords: pre-service teachers; beliefs; lesson study; reformation; schools

\begin{abstract}
ABSTRAK
Penelitian ini bertujuan untuk menjabarkan kepercayaan calon guru serta melihat perspektif calon guru dalam menerapkan praktik mengajar mikro (microteaching) melalui kegiatan Lesson Study khususnya menerapkan belajar berpusat pada siswa. Penelitian survey ini melibatkan mahasiswa di tahun keempat dan ketiga sebanyak 33 orang sebagai subjek penelitian. Pengambilan data kepercayaan calon guru melalui pengisian kuesioner serta hasil observasi yang dilakukan pada kelas. Keterampilan Dasar Mengajar dan Kegiatan Praktik Kerja Lapang. Metode analisis kualitatif dan pengelompokan data secara kuantitatif digunakan untuk mengetahui respon calon guru dalam kepercayaan menerapkan belajar berpusat pada siswa. Hasilnya kepercayaan calon guru masih berada pada level 2 (instruktif) hingga level 4 (responsif) baik pada aspek kepercayaan terhadap proses pembelajaran berpusat pada siswa dan aspek kepercayaan membangun pengetahuan oleh siswa. Level tertinggi dari kepercayaan calon guru yaitu level 5 (reformasi) belum dimiliki. Melalui analisis kepercayaan calon guru pada aspek-aspek tersebut dapat digunakan sebagai tolak ukur apakah proses pembelajaran sudah berpusat pada siswa atau masih berpusat pada kendali guru.
\end{abstract}

Kata kunci: calon guru; kepercayaan; Lesson Study; reformasi; sekolah

\section{PENDAHULUAN}

Pembelajaran berpusat pada siswa (Student Centered Learning) memberikan peluang untuk pengalaman belajar yang lebih banyak diperoleh dan dibangun oleh siswa. Namun, praktik menuju pembelajaran berpusat pada siswa belum

Cara mengutip: Lathifah, A.S., Istikomayanti, Y. \& Mitasari, Z. (2021). Kepercayaan Calon Guru sebagai Faktor Keberhasilan Pembelajaran Berpusat pada Siswa. Inteligensi: Jurnal Ilmu Pendidikan, 4(1), 9-18 
sebagian besar dipraktikkan oleh guruguru. Hasil penelitian menyebutkan perlunya keterampilan pedagogik terus dikembangkan baik pada guru sebagai kegiatan pengembangan profesionalisme dan juga untuk calon guru sebagai pengalaman dan pembentukan persepsi (Hidayat, 2019 ; Andina, 2018)

Beberapa penelitian menyebutkan lamanya waktu dan pengalaman mengajar tidak sejalan dengan peningkatan kompetensi profesional guru Andina (2018) dan Saito et al. (2006). Banyak masalah yang terjadi khususnya data penelitian Andina (2018) menunjukkan beberapa guru masih belum berani merubah cara atau strategi pembelajaran yang berpusat pada siswa. Sebagian guru juga masih memiliki keterampilan profesional dalam rata-rata.

Kepercayaan yaitu suatu nilai dari dalam diri seseorang yang mempengaruhi perilakunya. Dalam taraf tingkatan kognitif, nilai atau value adalah keyakinan yang berhubungan dengan keadaan yang diinginkan. Nilai adalah kemampuan memilih, mengevaluasi perilaku, dan peristiwa, dan diurutkan berdasarkan kepentingan relatif ke nilai lain untuk membentuk sistem prioritas nilai. Penerapan nilai dalam masyarakat berupa agama, kepercayaan, kebudayaan, serta paham baru. Nilai ini sulit untuk berubah, mampu melampaui batas ruang waktu, dan perubahannya hanya sedikit demi sedikit.

Pembentukan nilai dalam diri guru untuk menyelenggarakan pembelajaran berpusat pada siswa masih belum dapat dipraktikkan secara terampil oleh beberapa calon guru dan juga guru menurut data penelitian Andina, (2018) dan Widjaja et al., (2015). Melalui pendekatan analisis kepercayaan sebagai perspektif guru diharapkan dapat menjadi pengukuran kualitas aspek pedagogik guru secara kuantitatif. Selain itu, hal ini sebagai upaya penelitian ini dalam memperbaiki rancangan kurikulum kepada calon guru.

Praktik pembelajaran oleh mahasiswa dilakukan dalam mata kuliah Keterampilan Dasar Mengajar (KDM) di semester 6 (enam) serta Praktik Lapangan Persekolahan (PLP) di semester 7 (tujuh). Sehingga mahasiswa angkatan keempat telah lebih banyak melakukan praktik mengajar mikro dibandingkan dengan mahasiswa angkatan ketiga. Dalam penelitian ini kepercayaan calon guru pada aspek kepercayaan terhadap proses pembelajaran dan kepercayaan terhadap pengetahuan akan dikaji.

Aspek kepercayaan pada proses pembelajaran meliputi keterampilan mengelola kelas dengan strategi pembelajaran yang dipilih, mengetahui telah terjadi proses belajar pada siswa dan telah terjadi lingkungan belajar di kelas. Kepercayaan pada pengetahuan yaitu meliputi aspek keyakinan menentukan materi esensial dan non-esensial, keputusan menuju ke materi selanjutnya dan memerankan posisi guru dan siswa sebagai ko-konstruktor pengetahuan.

Strategi perkuliahan yang dilakukan pada mata kuliah KDM menerapkan Lesson Study (LS) sebagai sarana proses belajar antara mahasiswa calon guru. Melalui strategi ini mahasiswa dapat merencanakan, melaksanakan dan mengobservasi pembelajaran, serta merefleksi pembelajaran bersama-sama. Kegiatan LS yang diterapkan lebih ditekankan pada penilaian teknik keterampilan dasar mengajar guru. Meliputi teknik bertanya, teknik membuka pembelajaran, menggunakan media 
pembelajaran, teknik penguatan, dan teknik menutup pembelajaran. Pada mata kuliah ini dimodifikasi dengan kegiatan LS sehingga memungkinkan mahasiswa bisa mengobervasi dan menilai strategi serta teknik mengajar yang dipraktikkan oleh temannya.

LS telah banyak disebarkan di Indonesia yang berawal dari para ahli di Jepang dan Indonesia yang berkolaborasi (Saito et al., 2006) (Miharja et al., 2020). Namun, sebagian tahapan penerapan dari LS dengan tujuan peningkatan kolegialitas diantara sejawat guru masih sedikit yang berhasil mencapainya (Istikomayanti, 2019) Hasil penelitian ini di Kota Malang khususnya penerapan LS belum mencapai taraf peningkatan kolegialitas sejawat. LS masih digunakan sebagai sarana pembelajaran insidental dan setelah itu ditinggalkan (Istikomayanti, 2019). Hal ini perlu mendapat perhatian jika kita melihat apakah penerapan pembelajaran berpusat pada siswa di kelas juga sudah mencapai tujuan menjadi pebelajar sepanjang hayat baik untuk siswa dan juga guru.

Keberhasilan pembelajaran juga tidak bisa dilihat sesaat dari perolehan nilai akhir. Proses belajar siswa serta perubahan perilaku siswa dipandang lebih penting untuk dikembangkan terus menerus. Keterampilan abad-21 dan milenial 4.0 mengedepankan keterampilan berkolaborasi, berfikir kritis, kreatif, serta berkomunikasi dengan baik (Miharja et al., 2020). Hal ini perlu kita renungkan apakah selama ini pembelajaran telah mengutamakan peningkatan keterampilan tersebut. Menurut (Yakar \& Turgut, 2017) pengukuran terhadap penilaian kepercayaan guru dapat dilakukan melalui angket Kepercayaan Guru. Pertanyaan yang diberikan merupakan pertanyaan terbuka memungkinkan responden memberikan jawaban sesuai dengan bahasa dan penjelasan mereka sendiri. Kategori dalam kuesioner tersebut meliputi bagaimana strategi peningkatan proses belajar siswa di kelas, bagaimana pembagian peran guru dan siswa dalam kelas, bagaimana pembagian materi dan alur pembelajaran, bagaimana guru mengetahui telah terjadi pembelajaran pada siswa di kelas.

Tujuan penelitian ini sebagai upaya melakukan analisis kepercayaan calon guru yang merupakan suatu penilaian diri sendiri terhadap praktik mikro pembelajaran berpusat pada siswa. Penelitian ini dilakukan pada mahasiswa tingkat ketiga dan keempat dengan kurikulum berbasis KKNI (Kerangka Kualifikasi Nasional Indonesia).

\section{METODE PENELITIAN}

Penelitian ini merupakan penelitian survey yang mendata mahasiswa calon guru pada tahun ketiga dan tahun keempat di Universitas Tribhuwana Tunggadewi, Malang, Jawa Timur, Indonesia. Mahasiswa di tahun ketiga telah mendapatkan pengalaman mengajar mikro pada mata kuliah KDM melalui pendekatan Lesson Study (LS). Pengalaman yang diperolah mahasiswa tahun keempat lebih banyak yakni mengajar mikro pada mata kuliah KDM serta menerapkan praktik mengajar pada kegiatan praktik lapang.

Pada kegiatan LS mata kuliah KDM mahasiswa diberikan kesempatan mengajar satu kali dan menjadi observer pembelajaran serta menjadi siswa beberapa kali. Mahasiswa dibentuk menjadi beberapa kelompok yang bertanggung 
jawab menilai masing-masing anggota kelompoknya dalam aspek keterampilan dasar mengajar. Pada kegiatan PLP (Praktik Lapangan Persekolahan) mahasiswa diberikan kesempatan menyusun perangkat pembelajaran, menerapkan praktik mengajar, serta mengevaluasi pembelajarannya dalam kelompok.

Instrumen angket diberikan secara daring melalui aplikasi Google Form di akhir semester setelah kuliah tersebut. Sampel penelitian ditentukan dengan purposive sampling, yakni mahasiswa telah dipilih pada angkatan ketiga dan keempat. Hasil pengisian kuesioner terjaring sebanyak 33 (tiga puluh tiga) mahasiswa yang melakukan pengisian secara lengkap. Angket merupakan pertanyaan terbuka pada Tabel 1. yang bisa diisi sebanyak maksimal 100 (seratus) kata. Jawaban yang diberikan dikategorikan menjadi beberapa taraf yaitu respon tradisional (skor 1), respon instruktif (skor 2), respon transisional (skor 3), sangat merespon/responsif (skor 4), dan respon reformasi (skor 5) ada Tabel 2. Instrumen ini diadaptasi dari penelitian (Yakar \& Turgut, 2017).

Daftar pertanyaan angket respon tersebut sebagai berikut (Tabel 1.). Pertanyaan No. 1, 3, 6 dan 7 adalah pertanyaan kepercayaan calon guru terhadap proses pembelajaran

\section{Tabel 1. Aspek Pertanyaan Terbuka Angket Kepercayaan}

\footnotetext{
1. Bagaimana memaksimalkan proses belajar siswa?

2. Bagaimana memerankan guru dan siswa di kelas?

3. Bagaimana mengetahui siswa telah memahami pembelajaran?

4. Bagaimana menentukan materi esensial
}

(diajarkan) dan materi non-esensial (siswa belajar mandiri)?

5. Bagaimana menentukan waktu untuk pindah topik baru?

6. Bagaimana strategi pembelajaran Biologi/IPA yang terbaik?

7. Bagaimana mengetahui telah terjadi pembelajaran di kelas?

(Yakar \& Turgut, 2017)

Selanjutnya kategori respon mahasiswa dikategorikan dengan level (1) hingga level (5) sebagai berikut. Tabel 2.

\section{Tabel 2. Kategori Respon Mahasiswa Pada Aspek Kepercayaan (Yakar, 2016).}

Level 1 (Respon Tradisional): Respon ini fokus pada pembelajaran berpusat pada guru dan secara ketat percaya bahwa hal yang efisien adalah transfer pembelajaran dari guru ke siswa.

Level 2 (Respon Instruktif): Respon ini fokus pada pembelajaran berpusat pada guru, guru berhati-hati mempersiapkan instruksi siswa dan meminimalisir masalah perilaku siswa.

Level 3 (Respon Transisi): Respon ini fokus pada respon untuk peranan siswa namun belum secara lengkap mendampingi peranan siswa di kelas sebagai pendamping konstruksi pengetahuan.

Level 4 (Sangat Responsif): Respon ini menunjukkan guru menilai kolaborasi di kelas dan guru memiliki ketertarikan pada interaksi antar siswa untuk memecahkan masalah .

Level 5 (Respon Reformasi): Respon ini menunjukkan komitmen kepada siswa sebagai pembangun pengetahuan di kelas. Secara jelas guru telah menentukan peranan guru sebagai mediator di antara siswa dan pengetahuan awal siswa serta dengan pengetahuan disiplin ilmunya.

\section{HASIL DAN PEMBAHASAN}

Hasil dari kegiatan pembelajaran yang diberikan pada mahasiswa tahun ketiga dan keempat melalui mata kuliah Keterampilan Dasar Mengajar (KDM) serta kegiatan praktik Pengalaman Lapangan Persekolahan (PLP) yaitu 
mahasiswa telah menyusun perangkat pembelajaran, menerapkan praktik mengajar, serta mampu mengevaluasi pembelajarannya melalui kegiatan Lesson Study (LS). Respon mahasiswa calon guru pada aspek kepercayaan terhadap proses pembelajaran berpusat pada siswa serta kepercayaan terhadap pengetahuan lebih dominan pada respon instruktif (level 2), responsif (level 3), dan responsif (level 4), yang disajikan pada tabel 3 dan 4 berikut.

\section{Tabel 3. Hasil Pendataan Kepercayaan Calon Guru Terhadap Proses Pembelajaran}

\begin{tabular}{|c|c|c|c|c|}
\hline $\begin{array}{c}\text { No } \\
\text { Pertanyaan }\end{array}$ & Deskripsi Kepercayaan & $\begin{array}{l}\text { Kategori } \\
\text { Respon }\end{array}$ & Frekuensi & Persentase \\
\hline \multirow[t]{5}{*}{1} & \multirow{5}{*}{$\begin{array}{l}\text { Bagaimana memaksimalkan proses belajar } \\
\text { siswa }\end{array}$} & Tradisional & 2 & 6,3 \\
\hline & & Instruktif & 11 & 34,4 \\
\hline & & Transisional & 16 & 50 \\
\hline & & Responsif & 3 & 9,4 \\
\hline & & Reformasi & 0 & 0 \\
\hline \multirow[t]{5}{*}{3} & \multirow{5}{*}{$\begin{array}{l}\text { Bagaimana mengetahui siswa telah memahami } \\
\text { pembelajaran }\end{array}$} & Tradisional & 3 & 9,4 \\
\hline & & Instruktif & 7 & 21,9 \\
\hline & & Transisional & 19 & 59,4 \\
\hline & & Responsif & 2 & 6,3 \\
\hline & & Reformasi & 1 & 3,1 \\
\hline \multirow[t]{5}{*}{6} & \multirow{5}{*}{$\begin{array}{l}\text { Bagaimana strategi pembelajaran Biologi/IPA } \\
\text { yang terbaik }\end{array}$} & Tradisional & 4 & 12,5 \\
\hline & & Instruktif & 10 & 31,3 \\
\hline & & Transisional & 12 & 37,5 \\
\hline & & Responsif & 5 & 15,6 \\
\hline & & Reformasi & 1 & 0 \\
\hline \multirow[t]{5}{*}{7} & \multirow{5}{*}{$\begin{array}{l}\text { Bagaimana mengetahui telah terjadi } \\
\text { pembelajaran di kelas. }\end{array}$} & Tradisional & 5 & 15,6 \\
\hline & & Instruktif & 6 & 18,8 \\
\hline & & Transisional & 11 & 34,4 \\
\hline & & Responsif & 10 & 31,3 \\
\hline & & Reformasi & 0 & 0 \\
\hline
\end{tabular}

Tabel 4. Hasil Pendataan Kepercayaan Calon Guru Terhadap Pengetahuan

\begin{tabular}{|c|c|c|c|c|}
\hline $\begin{array}{l}\text { No } \\
\text { Pertanyaan }\end{array}$ & Deskripsi Kepercayaan & $\begin{array}{l}\text { Kategori } \\
\text { Respon }\end{array}$ & Frekuensi & Persentase \\
\hline 2 & $\begin{array}{l}\text { Bagaimana memerankan guru dan siswa di } \\
\text { kelas }\end{array}$ & $\begin{array}{l}\text { Tradisional } \\
\text { Instruktif } \\
\text { Transisional } \\
\text { Responsif } \\
\text { Reformasi }\end{array}$ & $\begin{array}{c}0 \\
5 \\
18 \\
9 \\
0\end{array}$ & $\begin{array}{c}0 \\
15,6 \\
56,3 \\
28,1 \\
0\end{array}$ \\
\hline 4 & $\begin{array}{l}\text { Bagaimana menentukan materi esensial } \\
\text { (diajarkan) dan materi non-esensial }\end{array}$ & $\begin{array}{l}\text { Tradisional } \\
\text { Instruktif } \\
\text { Transisional } \\
\text { Responsif } \\
\text { Reformasi }\end{array}$ & $\begin{array}{c}1 \\
10 \\
18 \\
2 \\
1\end{array}$ & $\begin{array}{c}3,1 \\
31,3 \\
56,3 \\
6,3 \\
3,1\end{array}$ \\
\hline 5 & $\begin{array}{l}\text { Bagaimana menentukan waktu yang tepat untuk } \\
\text { pindah topik baru }\end{array}$ & $\begin{array}{l}\text { Tradisional } \\
\text { Instruktif } \\
\text { Transisional } \\
\text { Responsif } \\
\text { Reformasi }\end{array}$ & $\begin{array}{c}1 \\
14 \\
12 \\
5 \\
0\end{array}$ & $\begin{array}{c}3,1 \\
43,8 \\
37,5 \\
15,6 \\
0\end{array}$ \\
\hline
\end{tabular}


Pada aspek kepercayaan calon guru terhadap proses pembelajaran lebih dominan pada level 2 (instruktif) dan 3 (transisi). Respon ini ditunjukkan pada pertanyaan bagaimana memaksimalkan proses belajar yakni strategi, taktik dan cara fasilitasi pembelajaran serta pertanyaan bagaimana strategi terbaik pembelajaran IPA/Biologi. Pada aspek lain yaitu bagaimana guru mengetahui telah terjadi pembelajaran pada siswa paling dominan pada level 3 (transisi) dan level 4 (responsif). Hal ini menunjukkan mahasiswa telah terlatih secara konseptual dalam mengembangkan pembelajaran. Selain itu mahasiswa juga terlatih dalam menyusun strategi atau model pembelajaran. Meskipun belum secara keseluruhan mahasiswa memiliki keterampilan tersebut. Sebagian mahasiswa masih berada pada level 1 , dan 2 dimana proses belajar di kelas diyakini lebih berhasil jika guru memegang kendali penuh terhadap proses pembelajaran.

Secara deskriptif perrnyataan mahasiswa pada level 1 (tradisional) dan 2 (instruktif) sebagai berikut:

1) Seorang guru berperan penting dalam memahami karakter siswa dan situasi kelas dan menjaga kenyamanan kelas saat kegiatan belajar mengajar itu berlangsung.

2) Saya memaksimalkannya dengan waktu yang di berikan dan juga pemahaman yang di dapat siswa.

3) Menciptakan suasana belajar yang menyenangkan serta membangkitkan motivasi belajar siswa.

Pada pernyataan tersebut mahasiswa calon guru telah memiliki pemahaman yang baik terhadap proses dan strategi pembelajaran yang menyenangkan dan efektif. Namun, sangat sedikit pemahaman dan keterampilan mereka dalam menentukan suatu strategi untuk memaksimalkan kegiatan pembangun pengetahuan yang lebih banyak dilakukan siswa. Hal ini perlu menjadi perhatian untuk menentukan strategi dalam pembelajaran calon guru (Saito et al., 2006). Sedangkan deskripsi mahasiswa pada level 3 (transisional) dan level 4 (responsif) sebagai berikut.

1) Kita perlu menjaga agar informasi terorganisasi dengan baik dan memberi waktu bagi pelajar untuk mencerna materi, baik melalui bertanya atau kegiatan tindak lanjut. Dan setelah memberikan materi kepada siswa maka harus menyakan siswa mana materi yang di sudah dan belum di pahami.

2) Contoh inovasi pembelajaran yaitu pembelajaran kontekstual, karena dalam pembelajaran kita sebagai guru atau calon guru jangan hanya memberikan contoh yang ada dalam buku tapi bisa kita menghubungkan dalam kehidupan sehari-hari.sehingga mendorong siswa untuk dapat menerapkan dalam masyarakat.

3) Untuk mengetahui bahwa dikelas telah terjadi pembelajaran yaitu dengan melihat keterlibatan siswa di dalam kelas secara aktif selama proses pembelajaran.

Pada level 4 (responsif) lebih sedikit dibandingkan dengan pernyataan kepercayaan calon guru di level 3 (transisi). Sebagain besar calon guru masih meyakini kendali pembelajaran ada pada peranan Guru yang utama. Namun, calon guru belum menyadari bagaimana mengelola berbagai karakter siswa untuk bersama membangun pengetahuan. Hal ini menjadi penting untuk dikaji lebih lanjut. Hasil serupa juga dialami pada penelitian Saito et al. (2006). Hal yang sama juga masih terjadi pada aspek kepercayaan 
Guru pada pengetahuan. Pada butir pertanyaan "Bagaimana menentukan materi esensial dan non-esensial" sebagian besar mahasiswa telah mencapai level 3, 4 dan 5 (reformasi). Level ini dapat tercapai dengan baik dimana memang mahasiswa sering mempraktikkan cara menentukan materi esensial dan non-esensial sehingga lebih memudahkan dalam strategi pembelajaran. Namun, pada aspek lainnya yaitu bagaimana memerankan guru dan siswa serta bagaimana menentukan waktu untuk pindah ke materi, sebagian besar mahasiswa masih memegang teguh peranannya sebagai guru. Gurulah yang menjadi aktor utama dalam pembelajaran serta menentukan kapan pindah materi atau tidak. Bagaimana jika hal ini beralih pada keputusan siswa menentukan ketuntasan diri mereka sendiri.

\section{Kepercayaan Calon Guru Sebagai Keberhasilan Pembelajaran Berpusat pada Siswa}

Permasalahan kepercayaan calon guru perlu dikaji lebih mendalam sebagai evaluasi kurikulum dan perkuliahan yang telah diberikan. Pada aspek kepercayaan terhadap proses pembelajaran dan pada aspek kepercayaan terhadap pengetahuan telah tercapai pada kategori level 4 dan 5 namun juga masih ada sebagian pada level 1 dan 2. Analisis jawaban angket mahasiswa calon guru menunjukkan mereka sebagian telah memiliki persepsi terhadap pembelajaran berpusat pada siswa, berbagai strategi pembelajaran yang digunakan pada RPP (Rencana Pelaksanaan Pembelajaran). Namun, dalam penyusunan RPP tersebut disadari oleh Dosen Pengampu bahwa mahasiswa merasa kesulitan untuk mendetilkan tahapan belajar, alur pemikiran siswa dan memberikan umpan balik kepada siswa. Mahasiswa calon guru memiliki pengalaman mengobservasi pembelajaran yang sangat terbatas. Sehingga kesulitan saat menyusun skenario pembelajaran banyak terjadi.

Beberapa kegiatan untuk mengasah keterampilan perencanaan pembelajaran, mahasiswa calon guru diberikan aktivitas yakni mengobservasi pembelajaran melalui video pembelajaran dikarenakan pada masa pandemi. Hasil observasi pembelajaran selanjutnya didiskusikan dan dianalisis dalam kelompok. Namun, kegiatan ini belum berhasil meningkatkan keterampilan merencanakan pembelajaran khususnya pembelajaran yang berpusat pada siswa. Beberapa penelitian yang sama menyimpulkan diperlukan adanya kegiatan observasi pembelajaran dalam kelas model dimana guru dapat memberikan model dan diobservasi calon guru. Secara teknik pengajaran atau pedagogik sulit diperoleh dari video pembelajaran yang terpotong atau mengalami pengeditan. Dengan demikian, saran untuk peningkatan kepercayaan calon guru adalah dengan lebih banyak berinteraksi pada kelas nyata baik luring ataupun daring. Dimana calon guru dan guru serta dosen bisa berinteraksi membangun persepsi dan pandangan terhadap belajar berpusat pada siswa.

Pada masa pandemi ini, mahasiswa merupakan kategori mahasiswa yang cepat beradaptasi pada era perilaku baru. Mahasiswa mampu melakukan interaksi dengan kelompok secara virtual atau jarak jauh misalnya dalam menyusun rencana pembelajaran, mengevaluasi praktik guru model, dan memberikan penilaian sejawat. Mahasiswa juga melakukan praktik pembelajaran daring yang direkam melalui video dan akan dinilai oleh teman 
sejawatnya. Hal ini juga menjadi suatu keunggulan mahasiswa lebih cepat beradaptasi dengan teknologi serta berinteraksi secara virtual. Permasalahan kepercayaan guru pada level rendah yaitu 1-2 (tradisional-instruktif) menunjukkan bahwa calon guru masih belum bisa melihat sejauh mana siswa dapat belajar. Keterampilan ini perlu ditekankan kepada mahasiswa calon guru berupa pengalaman nyata untuk mengukur kebutuhan belajar siswa, tingkat belajar siswa, serta harapan belajar dari siswa seperti penelitian Taskin (2017) dan Alanazi (2019). Selain itu pada aspek pembagian peran siswa dan guru hanya tercapai $28,6 \%$ pada level responsif (level 4) yakni mampu menghargai setiap respon siswa dan mengarahkannya sebagai umpan balik. Pada aspek ini mahasiswa calon guru belum memiliki pemahaman belajar merdeka yakni siswa bisa menentukan sendiri cara belajar mereka di kelas. Data menunjukkan Calon Guru tetap memiliki kendali penuh terhadap proses pembelajaran, meskipun memberikan kesempatan siswa untuk berinteraksi dengan siswa lainnya dalam membangun pengetahuan, termasuk mengendalikan perilaku.

Para calon guru masih memiliki sedikit pengetahuan dan paham terhadap proses pembelajaran yang menyeluruh pada siswa. Hal yang perlu dikembangkan pada aspek selain membangun pengetahuan yakni kemampuan siswa dalam mengembangkan komunikasi, kematangan emosional, serta perilaku sosial dalam kegiatan belajar yang juga ditemukan pada beberapa penelitian Aimah \& Purwanto (2018), Saito et al., (2006), dan Cameron \& Campbell (2011). Menurut penelitian (Miharja et al., 2020) melalui strategi penguatan aspek sosial dan emosional siswa dapat meningkatkan interaktifitas siswa dalam belajar. Pembelajaran berpusat pada siswa adalah proses siswa belajar dan berinteraksi dengan sesamanya dan membangun kesepahaman konsep atau materi yang dibelajarkan.

Pada aspek kepercayaan guru terhadap proses pembelajaran dan pengetahuan siswa berhubungan dengan keterampilan pedagogik meliputi manajemen kelas, penilaian siswa, dan penyusunan rencana pembelajaran dan proses belajar siswa disebut sebagai pengetahuan pedagogik (Hidayat, 2019). Selain aspek pengetahuan pedagogik guru juga perlu memiliki aspek pengetahuan pedagogik bidang studinya dan pengetahuan tentang teknologi pembelajarannya. Dengan demikian, semakin banyak mahasiswa calon guru memperoleh pengalaman belajar mengajar maka semakin bervariasi pengetahuan yang diperolehnya dan diharapkan mampu meningkatkan kepercayaan calon guru. Penelitian yang lain juga melakukan pengukuran terhadap keterampilan guru dalam menyusun rencana pembelajaran dengan isntrumen tertentu (Konig, et.al, 2020). Melalui penelitian tersebut dapat dikembangkan pengukuran kualitas keterampilan guru dalam menyusun rencana pembelajaran

\section{SIMPULAN}

Kesimpulan pada penelitian ini menunjukkan kepercayaan calon guru masih berada pada level 2 (instruktif) hingga level 4 (responsif) baik pada aspek kepercayaan terhadap proses pembelajaran berpusat pada siswa dan aspek kepercayaan membangun pengetahuan oleh siswa. Level tertinggi dari kepercayaan calon guru yaitu level 5 
(reformasi) belum dimiliki atau belum tercapai. Hal ini menjadi saran untuk evaluasi pembelajaran yang telah ditempuh mahasiswa calon guru. Dengan merancang kembali strategi pembelajaran untuk peningkatan kompetensi pedagogik mahasiswa, diharapkan dapat merubah pemahaman menjadi tindakan yang diyakini belajar berpusat pada siswa adalah proses yang terbaik. Hal ini diharapkan dapat dilaksanakan pada kesempatan penelitian berikutnya.

\section{DAFTAR PUSTAKA}

Aimah, S., \& Purwanto, B. (2018). Indonesian Teachers' Perception on the Implementation of Lesson Study: Exploring Teachers' Awareness of Pedagogical Knowledge. Arab World English Journal, 9(4), 380-391. https://doi.org/10.24093/awej/vol9no 4.28

Andina, E. (2018). Efektivitas Pengukuran Kompetensi Guru. Aspirasi: Jurnal Masalah-Masalah Sosial, 9(2), 204220.

https://doi.org/10.46807/aspirasi.v9i2. 1103

Hidayat. A. (2019). Developing and Validating A Technological Pedagogical Content Kknowledge (TPACK) Instrument For Secondary Pysics Preservice Teachers In Indonesia. Unnes Science Education Journal, 8(1), 31-40.

Cameron, L., \& Campbell, C. (2011). Learning Designs: A pre-service teacher perspective. World Conference on Educational Multimedia, ..., January, 2869-2875. http://www.editlib.org/p/38271/

Alanazi, M. (2019). A Study of the PreService Trainee Teachers Problems in Designing Lesson Plans. Arab World English Journal, 10(1), 166-182. https://doi.org/10.24093/awej/vol10n o1.15

Istikomayanti, Y; Lathifah A.S.; Mitasari Z. (2019). Collegiality as a Key for
Improving Students Success in Lesson Study Practices. International Conference on Mathematics and Science Education, 3(1), 184-196. https://doi.org/10.1017/CBO9781107 415324.004

Konig, J. Albert B. C. B. (2020). 2020. Konig et al. Pre-service teachers' generic and subject-specific lessonplanning skills_On learning adaptive teac _ Enhanced Reader.pdf (pp. 131-150).

Miharja, F. J., Nurwidodo, N., Wahyuningrum, L., Iffah, A. H., \& Eskasasnanda, I. D. P. (2020). Tokkatsu: Initiating students' collaborative activities in lesson study piloting school. Jurnal Pendidikan Progresif, 10(1), 63-72. https://doi.org/10.23960/jpp.v10.i1.20 2008

Saito, E., Harun, I., Kuboki, I., \& Tachibana, H. (2006). Indonesian lesson study in practice: Case study of indonesian mathematics and science teacher education project. Journal of In-Service Education, 32(2), 171-184. https://doi.org/10.1080/13674580600 650872

Taskin, S. and. (2017). Exploring Preservice Teachers' Perceptions of Lesson Planning in Primary Education. Journal of Education and Practice, 8(12), 57-63. www.iiste.org Widjaja, W., Vale, C., Groves, S., \& Doig, B. (2015). Teachers' professional growth through engagement with lesson study. Journal of Mathematics Teacher Education, 20(4), 357-383. https://doi.org/10.1007/s10857-0159341-8

Yakar, Z., \& Turgut, D. (2017). Effectiveness of Lesson Study Approach on Preservice Science Teachers' Beliefs. International Education Studies, 10(6), 36. https://doi.org/10.5539/ies.v10n6p36 
Inteligensi : Jurnal Ilmu Pendidikan Vol. 4, No.1, 2021. Hal 9-18 